\title{
ANALISIS PILAR INFRASTRUKTUR YANG MEMPENGARUHI DAYA SAING DAERAH KABUPATEN WONOGIRI
}

\author{
Lilyk Eka Suranny \\ Peneliti Ahli Muda Bappeda dan Litbang Kabupaten Wonogiri \\ lilykekasuranny@gmail.com
}

\begin{abstract}
Infrastructure is one of the pillars that influence regional competitiveness. The purpose of this study is to analyze the infrastructure pillars that influence the Regional Competitiveness Index (IDSD) of Wonogiri Regency and provide recommendations to increase the competitiveness of Wonogiri Regency. The data collected is secondary data from the Central Agency on Statistics (BPS) and other official institutions. Data analysis used quantitative and qualitative descriptive analysis. The results showed that the IDSD value of Wonogiri Regency in the infrastructure pillar was still below the average of the Regency / city competitiveness index in Central Java. Efforts that can be made by the government in overcoming infrastructure problems are by collaborating on APBD budget funds and village / kelurahan funds for infrastructure development/maintenance both for transportation infrastructure, clean water and electricity infrastructure.
\end{abstract}

Keywords: regional competitiveness index (IDSD), infrastructure pillar, Wonogiri Regency

Abstraksi. Infrastuktur merupakan salah satu pilar yang berpengaruh pada daya saing daerah. Tujuan dari penelitian ini adalah menganalisis pilar infrastruktur yang mempengaruhi Indeks Daya Saing Daerah (IDSD) Kabupaten Wonogiri serta memberikan rekomendasi guna peningkatan daya saing daerah Kabupaten Wonogiri. Data yang dikumpulkan merupakan data sekunder yang berasal dari Badan Pusat Statistik dan institusi resmi lainnya. Analisis data menggunakan analisis deskriptif kuantitatif dan kualitatif. Hasil penelitian menunjukkan bahwa nilai IDSD Kabupaten Wonogiri pada pilar infrastruktur masih dibawah rata-rata nilai indeks daya saing Kabupaten/kota di Jawa Tengah. Upaya yang dapat dilakakukan pemerintah dalam mengatasi permasalahan infrastruktur yaitu dengan melakukan kolaborasi anggaran dana APBD dan dana desa/kelurahan untuk pembangunan/perawatan infrastruktur baik untuk infrastruktur transportasi, infrastruktur air bersih dan kelistrikan.

\section{Kata kunci: indeks daya saing daerah, pilar infrastruktur, Kabupaten Wonogiri}

\section{PENDAHULUAN}

Pembangunan daerah merupakan bagian dari integral pembangunan nasional dan sejalan dengan prinsipprinsip kebijakan desentralisasi dan otonomi daerah. Dengan terbitnya Undang-undang Nomor 23 Tahun 2014 tentang Pemerintahan daerah maka konsekuensinya adalah adanya penyerahan kewenangan Pemerintah Pusat kepada Pemerintah Daerah untuk mengatur dan mengurus rumah tangganya sendiri. Adanya desentralisasi kebijakan dari pemerintah pusat kepada pemerintah daerah tersebut telah memberikan kewenangan yang luas kepada pemerintah daerah untuk membuat kebijakan daerah dalam rangka 
memaksimalkan

pelayanan, meningkatkan peran serta, prakarsa dan pemberdayaan masyarakat yang bertujuan pada peningkatan kesejahteraan masyarakat.

Sejalan dengan hal tersebut maka penyelenggaraan pemerintahan pada era desentralisasi (otonomi daerah) harus mampu meningkatkan kemandirian daerah dan daya saing daerah yang berimplikasi pada peningkatan kualitas hidup masyarakat kearah yang lebih baik. Oleh karena itu, pemerintah daerah dituntut untuk lebih profesional dalam melakukan pengelolaan terhadap sumber daya yang dimilikinya, serta mampu melakukan percepatan dalam rangka mendorong peningkatan pelaksanaan diseluruh aspek.

Daya saing (competitiveness) suatu daerah merupakan salah satu parameter dalam konsep pembangunan daerah berkelanjutan. Secara konsep, daya saing menunjukkan kemampuan suatu daerah dibandingkan dengan daerah lain dalam menetapkan strategi yang tepat dalam meningkatkan kesejahteraan masyarakatnya. Daerah harus mampu mencari dan mengenal potensi yang akan dikembangkan dan dapat berdampak pada meningkatnya kesejahteraan masyarakat setempat. Semakin tinggi tingkat daya saing suatu daerah, diharapkan akan semakin mempercepat kemampuan daerah dalam meningkatkan kesejahteraan masyarakatnya.

Mengingat betapa pentingnya daya saing, maka daya saing tersebut menjadi tiga prioritas penting dari sembilan visi, misi, dan program aksi Presiden Joko Widodo yang dikenal dengan sebutan Nawacita. Tiga prioritas yang terkait dengan daya saing adalah (1) meningkatkan kualitas hidup manusia;
(2) meningkatkan produktivitas rakyat dan daya saing di pasar internasional; dan (3) mewujudkan kemandirian ekonomi dengan menggerakkan sektor-sektor strategis ekonomi domestik. Selain dari itu, arah Pembangunan Nasional Jangka Panjang sebagaimana termuat dalam RPJMN Tahun 2015 - 2019 adalah memantapkan pembangunan secara menyeluruh dengan menekankan pembangunan keunggulan kompetitif perekonomian yang berbasis SDA yang tersedia, SDM yang berkualitas, serta kemampuan iptek (Kemenristekdikti, 2018).

Sejalan dengan hal tersebut, maka pemerintah pusat melalui Kementrian Dalam Negeri mengadakan kegiatan Indeks Inovasi Daerah dan Kementrian Riset, Teknologi dan Perguruan Tinggi mengadakan Kegiatan Indeks Daya Saing Daerah. Penghargaan Inovasi dan Daya Saing Daerah ini diberikan kepada Pemerintah Kabupaten/Kota di Indonesia sebagai apresiasi atas prestasi dalam penguatan inovasi daerah sehingga menghasilkan nilai tambah, baik dalam bentuk komersial, ekonomi maupun sosial budaya sehingga berdampak kepada peningkatan daya saing dan kesejahteraan masyarakat yang tinggi dan berkelanjutan.

$\begin{array}{rcrr}\text { Indeks Daya } & \text { Saing } & \text { Daerah } \\ \text { (IDSD) adalah } & \text { ukuran } & \text { yang }\end{array}$ menggambarkan kondisi dan kemampuan suatu daerah dalam mengoptimalkan pemanfaatan seluruh potensi yang dimilikinya guna tercapainya kesejahteraan yang tinggi dan berkelanjutan. Daerah dengan skor IDSD tertinggi diartikan sebagai daerah yang berhasil secara optimal memanfaatkan segala potensi yang dimilikinya sebagai upaya menciptakan daya saing dan 
kesejahteraan yang tinggi dan berkelanjutan. Dalam Penghargaan Daya Saing Daerah oleh Kemenristekdikti ada 12 Pilar/Variabel (Pilar Kelembagaan, Pilar Infrastruktur, Pilar Perekonomian Daerah, Pilar Kesehatan, Pilar Pendidikan dan Keterampilan, Pilar Efesiensi Pasar Produk, Pilar Ketenagakerjaan, Pilar Akses Keuangan, Pilar Ukuran Pasar, Pilar Kesiapan Teknologi, Pilar Dinamika Pasar, Pilar Kapasitas Inovasi) yang menjadi komponen daya saing daerah (Kemenristekdikti, 2018).

Kelengkapan sarana dan prasana wilayah (infrastuktur) akan mendorong peningkatan perekonomian masyarakat. Olehkarena itu, kondisi infrastruktur yang baik merupakan prasyarat utama bagi upaya meningkatkan daya saing daerah maupun perkembangan perekonomian. Berdasarkan pada hal tersebut maka tujuan dari penelitian ini adalah untuk menganalisis pilar infrastruktur yang mempengaruhi Indeks Daya Saing Daerah Kabupaten Wonogiri. Selanjutnya akan direkomendasikan masukan bagi peningkatan dan rencana tindak guna peningkatan daya saing daerah Kabupaten Wonogiri khususnya pada pilar infrastruktur.

\section{METODE PENELITIAN}

Ada beberapa tahapan pelaksanaan kegiatan perhitungan nilai indeks daya saing daerah (IDSD). Diawali dengan mengisi 90 pertanyaan/indikator/kuisioner yang dilengkapi dengan data dukung secara online melalui web http://indeks.inovasi.ristekdikti.go.id.
Selanjutnya verifikasi data dukung yang dilampirkan dalam pengisian kuesioner dan sistem secara otomatis akan melakukan perhitungan nilai indeks daya saing setiap daerah. Hasilnya akan didapatkan skor indeks untuk setiap komponen IDSD baik nilai setiap dimensi, nilai setiap pilar, dan nilai per aspek/faktor maupun skor IDSD total. Tahapan perhitungan nilai IDSD terlampir pada gambar 1. Hasil perhitungan nilai IDSD Kabupaten Wonogiri tersebut selanjutnya dianalisis. Dalam penelitian ini akan dilakukan analisis pada pilar infrastruktur. Pilar infrastruktur terdiri dari dimensi/indikator infrastruktur transportasi dan dimensi infrastruktur air bersih dan kelistrikan. Data yang digunakan dalam penelitian ini adalah data sekunder yang diperoleh dari BPS Kabupaten Wonogiri, Bappeda Provinsi Jawa Tengah, EDSM Provinsi Jawa Tengah dan data dukung lainnya. Metode pengumpulan data yang digunakan dalam penelitian ini adalah metode dokumentasi dilakukan dengan mempelajari dokumen terkait data yang dibutuhkan dalam penelitian. Hasil dari perhitungan indikator pada pilar/variabel infrastruktur tersebut kemudian dibandingkan dengan hasil rata-rata variabel infrastruktur pada seluruh Kabupaten/Kota di Jawa Tengah. Selanjutnya dilakukan analisis atas hasil tersebut menggunakan analisis deskriptif kuantitatif dan kualitatif. Dari hasil analisis tersebut akan direkomendasikan kebijakan untuk meningkatkan daya saing daerah Kabupaten Wonogiri khususnya pada pilar infrastruktur. 


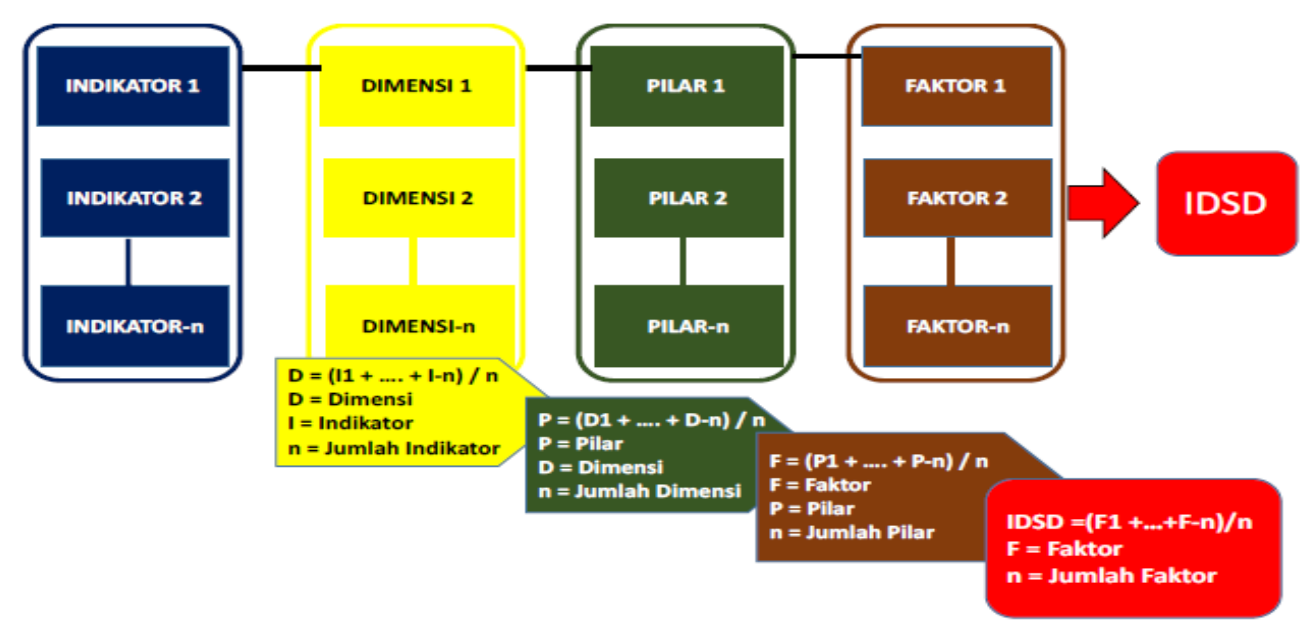

Sumber: Pedoman Teknis Penilaian IDSD Bappeda Provinsi Jawa Tengah 2018

Gambar 1. Tahapan dan Rumus Perhitungan Nilai Indeks Daya Saing Daerah

\section{HASIL DAN PEMBAHASAN}

Pemerintah pusat melalui Kementrian Riset, Teknologi dan Perguruan Tinggi Republik Indonesia mengadakan kegiatan Anugerah Iptek Budhipraja. Berdasarkan hasil penilaian diperoleh nilai indek daya saing daerah Kabupaten Wonogiri adalah 4,646. Dari penilaian setiap pilar pembentuk IDSD, diperoleh nilai pilar infrastruktur adalah 2.5. Nilai ini paling rendah diantara pilar lainnya apabila dibandingkan dengan nilai rata-rata setiap pilar pembentuk IDSD Kab/kota Se-Jawa Tengah. Dalam penelitian ini sebagai pembanding adalah nilai IDSD kab/kota se-Jawa Tengah pada setiap komponen pilar pembentuknya. Pada pilar infrastruktur dan pilar pendidikan\&ketrampilan nilai IDSD Kabupaten Wonogiri masih dibawah rata-rata Kab/Kota di Jawa Tengah. Namun untuk pilar infrastruktur nilainya paling rendah diantara pilar pembentuk Indeks Daya Saing Daerah di Kabupaten Wonogiri. Nilai hasil IDSD Kabupaten Wonogiri dibandingkan dengan nilai rata-rata Kab/Kota di Jawa Tengah tersaji dalam Tabel 1.

Tabel 1.

Nilai hasil IDSD Kabupaten Wonogiri, nilai median dan nilai rata-rata Kab/Kota di Jawa Tengah

\begin{tabular}{|c|c|c|c|c|c|c|c|c|c|c|c|c|c|}
\hline & Pilar & $\begin{array}{l}\text { Dinam } \\
\text { ika } \\
\text { Bisnis }\end{array}$ & $\begin{array}{l}\text { Kapasi } \\
\text { tas } \\
\text { Inovasi }\end{array}$ & $\begin{array}{l}\text { Kesia } \\
\text { pan } \\
\text { Tekn } \\
\text { ologi }\end{array}$ & $\begin{array}{l}\text { Akse } \\
\text { S } \\
\text { Keua } \\
\text { ngan }\end{array}$ & $\begin{array}{l}\text { Efisie } \\
\text { nsi } \\
\text { Pasar } \\
\text { Prod } \\
\text { uk }\end{array}$ & $\begin{array}{l}\text { Kete } \\
\text { naga } \\
\text { kerja } \\
\text { an }\end{array}$ & $\begin{array}{l}\text { Ukur } \\
\text { an } \\
\text { Pasar }\end{array}$ & $\begin{array}{l}\text { Infra } \\
\text { struk } \\
\text { tur }\end{array}$ & $\begin{array}{l}\text { Kele } \\
\text { mbag } \\
\text { aan }\end{array}$ & $\begin{array}{l}\text { Pere } \\
\text { kono } \\
\text { mian } \\
\text { Daer } \\
\text { ah }\end{array}$ & $\begin{array}{l}\text { Kese } \\
\text { hatan }\end{array}$ & $\begin{array}{l}\text { Pendi } \\
\text { dikan } \\
\text { dan } \\
\text { Ketr } \\
\text { ampil } \\
\text { an }\end{array}$ \\
\hline 1 & $\begin{array}{l}\text { Rata-rata } \\
\text { Kab/Kota }\end{array}$ & 3,515 & 2,824 & 3,914 & 3,251 & 4,110 & 4,171 & 4,948 & 3,061 & 4,561 & 4,339 & 5,329 & 2,800 \\
\hline 2 & Median & 3,4 & 2,667 & 3,9 & 3,286 & 4,056 & 4,333 & 5 & 3,125 & 4,875 & 4,333 & 5,5 & 2,743 \\
\hline 3 & Wonogiri & 5,3 & 3,7 & 5,6 & 3,857 & 5,722 & 4,5 & 7 & 2,5 & 5,25 & 4,4 & 6 & 2,792 \\
\hline
\end{tabular}

Sumber: Bappeda Provinsi Jawa Tengah, 2018 


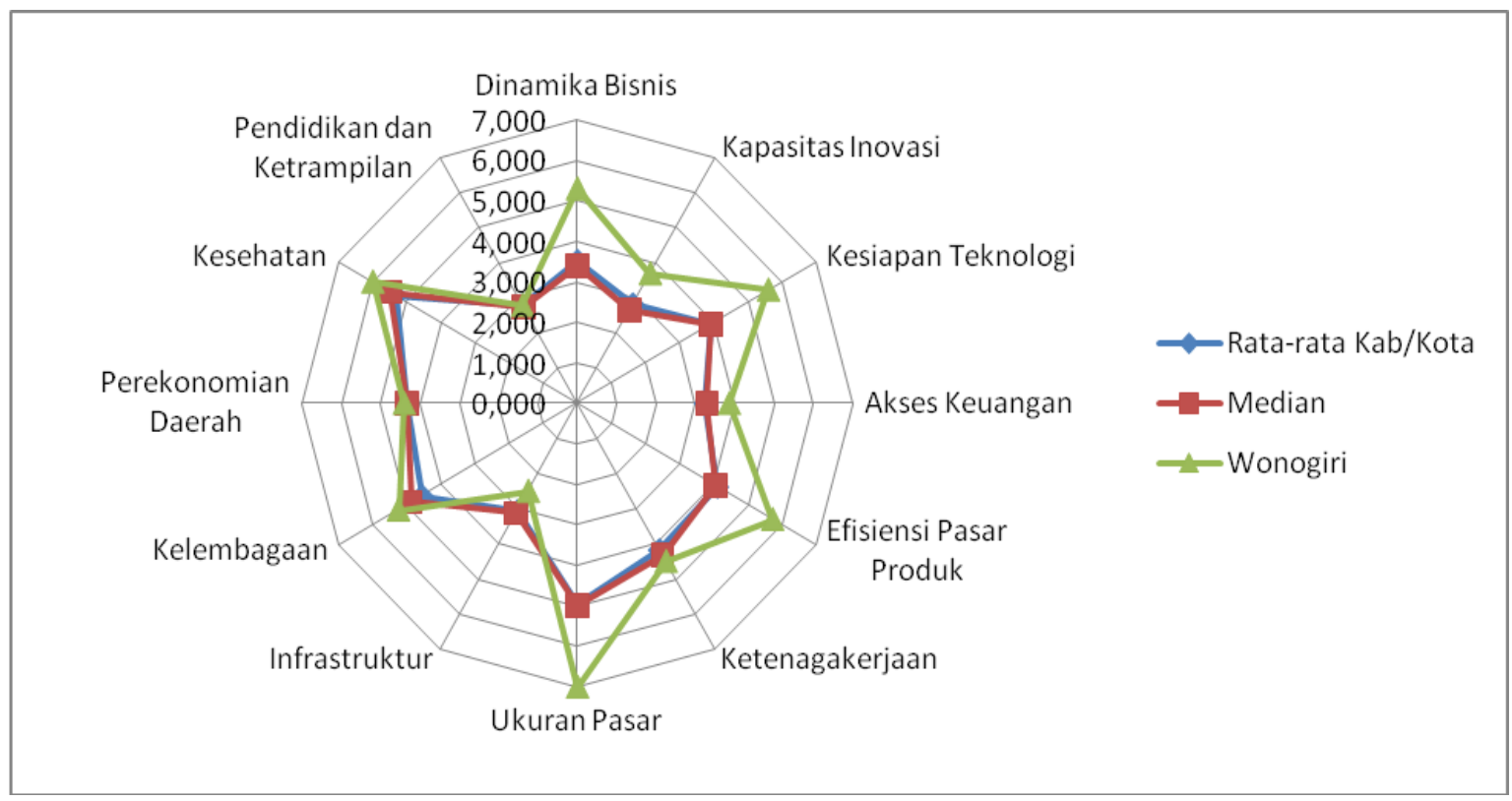

Gambar. 2

Nilai IDSD rata-rata Kab/Kota di Jawa Tengah, nilai median IDSD dan nilai IDSD Kabupaten Wonogiri berdasarkan 12 pilar pembentuk IDSD

Berdasarkan gambar 2, nilai Indek Daya Saing Daerah (IDSD) Kabupaten Wonogiri paling rendah pada pilar infrastruktur. Dalam penilaian indeks daya saing daerah, komponen pembentuk pilar infrastruktur terdiri dari infrastruktur transportasi, infrastruktur air bersih dan kelistrikan. Luas wilayah Kabupaten Wonogiri memiliki luasan nomor 3 seJateng setelah Kab. Cilacap dan Kab. Grobogan (BPS Jateng, 2018). Kabupaten Wonogiri memiliki 26 kecamatan yang terdiri dari 251 desa dan 43 kelurahan. Atribut tentang Infrastruktur transportasi yakni tentang kondisi jalan dan sarana angkutan yang ada di Wonogiri. Panjang jalan permukaan yang baik di Kabupaten Wonogiri sebesar 537,7 km, panjang jalan permukaan yang sedang sebesar 289,06 km, panjang jalan permukaan yang rusak sebesar 200,81 km dan jalan rusak berat $10,9 \mathrm{~km}$. Pembangunan infrastruktur memiliki peran yang penting dalam perekonomian masyarakat. Melalui akses infrastruktur seperti jalan misalnya, dengan kondisi jalan yang baik maka akan mempermudah aktivitas masyarakat dalam melakukan kegiatan di berbagai bidang. Hal ini sesuai dengan pernyataan Wasilan (2015), bahwa infrastruktur yang memadai sebagai penunjang aktivitas ekonomi akan berdampak pada pertumbuhan ekonomi. Infrastruktur jalan dalam kondisi baik akan mempermudah mobilisasi penyaluran barang dan jasa serta mengurangi akses masyarakat yang terisolir.

Perbaikan infrastruktur jalan di Kabupaten Wonogiri menjadi salah satu prioritas dalam pembangunan daerah. Pemerintah Kabupaten Wonogiri telah mengalokasikan anggaran untuk infrastruktur jalan dan jembatan dari tahun 2016-2018 sebesar Rp 503.711.249.096 atau 26,1\% terhadap total belanja langsung. Kedepannya akan terus dilakukan perbaikan dan 
pembangunan infrastruktur sesuai dengan fokus prioritas pembangunan di Kabupaten Wonogiri yang salah satunya yaitu pembangunan infrastruktur untuk mengurangi kesenjangan antar wilayah. Data panjang jalan menurut kecamatan dan kondisi jalan ditunjukkan pada tabel 2

Tabel 2.

Panjang Jalan Menurut Kecamatan dan Kondisi Jalan di Kabupaten Wonogiri Tahun 2016

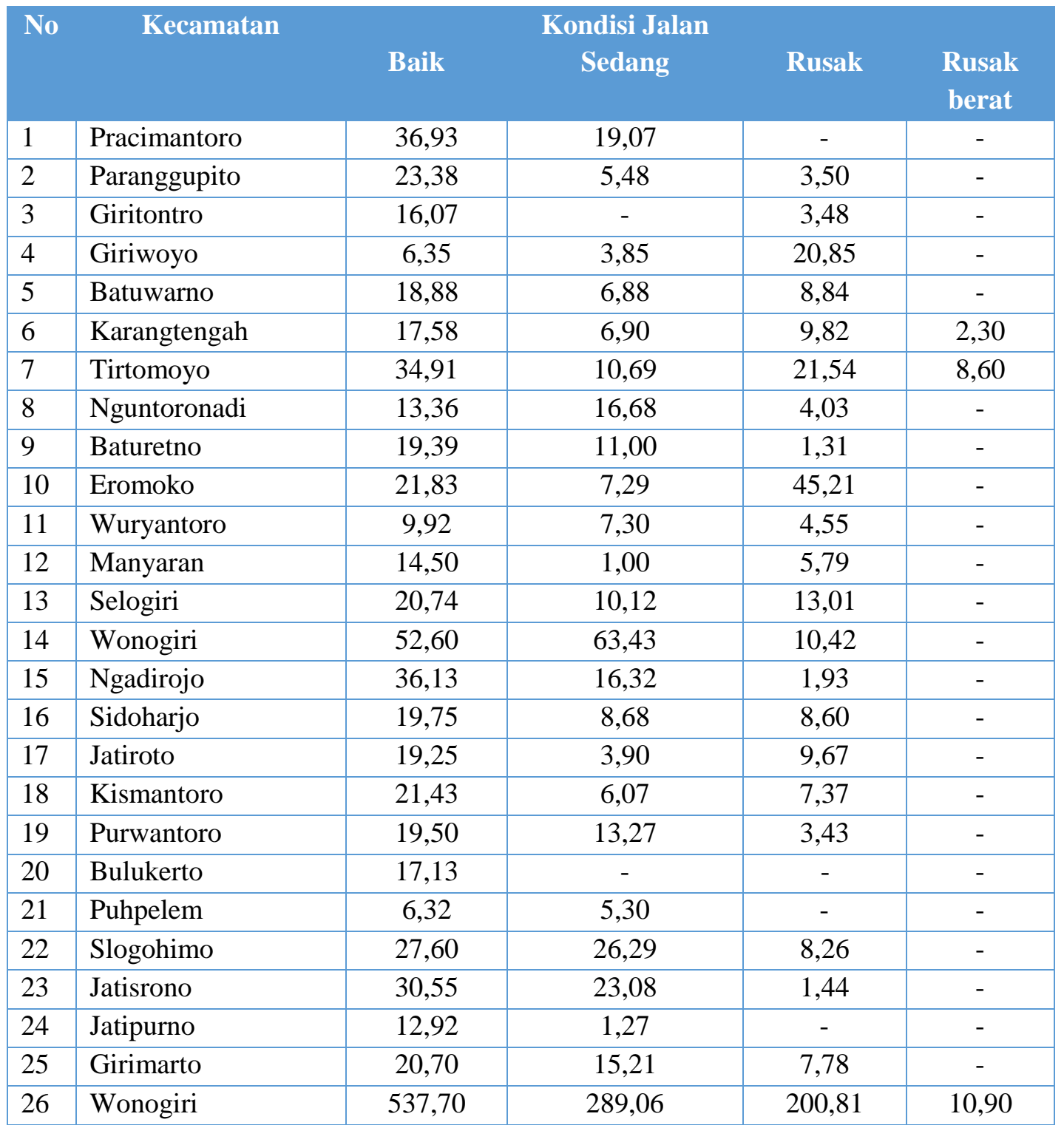

Sumber : Kabupaten Wonogiri Dalam Angka 2017

Selain hal tersebut diatas rendahnya nilai pilar infrastruktur ini juga diakibatkan dari kontribusi nilai PDRB dari sektor transportasi dan pergudangan, sektor pengadaan listrik dan air bersih yang rendah. Persentase kontribusi nilai PDRB perolehan dari sektor transportasi dan pergudangan terhadap PDRB total Kabupaten Wonogiri tahun 2016 adalah 5,88\% (Wonogiri Dalam Angka, 2017). Sedangkan persentase kontribusi nilai PDRB perolehan dari sektor pengadaan listrik terhadap PDRB total Kabupaten Wonogiri tahun 2016 adalah 0,07\% 
(Wonogiri Dalam Angka, 2017). Rendahnya kontribusi sektor transportasi terhadap PDRB di Kabupaten Wonogiri disebabkan kurangnya pemanfaatan transportasi umum oleh masyarakat. Masyarakat Wonogiri saat ini lebih banyak memanfaatkan transportasi pribadi dalam menjalankan aktivitasnya sehari-hari. Hal tersebut berimbas pada beberapa pengusaha angkutan umum yang mengalami gulung tikar. Dari sektor pengadaan listrik dan air kebanyakan dimanfaatkan oleh rumah tangga masyarakat dan perusahaan/pabrik di Kabupaten Wonogiri. Jumlah pabrik/perusahaan tidak banyak, sehingga pada sektor ini berkontribusi rendah. Persentase distribusi PDRB berdasarkan lapangan usaha Kabupaten Wonogiri tahun 2013-2016 tersaji dalam tabel 3.

Tabel 3.

Distribusi Persentase Produk Domestik Regional Bruto Atas Dasar harga Berlaku Menurut Lapangan Usaha di Kabupaten Wonogiri (persen), 2013-2016

\begin{tabular}{|l|l|r|r|r|r|}
\hline No & \multicolumn{1}{|c}{ Lapangan Usaha } & $\mathbf{2 0 1 3}$ & $\mathbf{2 0 1 4}$ & $\mathbf{2 0 1 5}$ & \multicolumn{1}{|c|}{$\mathbf{2 0 1 6}$} \\
\hline 1 & Pertanian, Kehutanan, dan Perikanan & 35,83 & 34,23 & 33,65 & 32,86 \\
\hline 2 & Pertambangan dan Penggalian & 3,13 & 3,24 & 3,40 & 3,32 \\
\hline 3 & Industri Pengolahan & 14,39 & 15,22 & 15,49 & 16,00 \\
\hline 4 & Pengadaan Listrik dan Gas & 0,06 & 0,06 & 0,06 & 0,07 \\
\hline 5 & $\begin{array}{l}\text { Pengadaan air, pengelolaan sampah, limbah } \\
\text { dan daur ulang }\end{array}$ & 0,07 & 0,07 & 0,07 & 0,06 \\
\hline 6 & Konstruksi & 6,24 & 6,40 & 6,52 & 6,54 \\
\hline 7 & Perdagangan besar dan eceran, reparasi & 16,15 & 15,80 & 15,62 & 15,59 \\
& mobil dan sepeda motor & & & & \\
\hline 8 & Transportasi dan pergudangan & 5,49 & 5,84 & 5,98 & 5,88 \\
\hline 9 & Penyediaan akomodasi dan makan minum & 2,27 & 2,27 & 2,29 & 2,38 \\
\hline 10 & Informasi dan komunikasi & 0,74 & 0,75 & 0,73 & 0,74 \\
\hline 11 & Jasa keuangan dan asuransi & 2,95 & 2,97 & 3,02 & 3,20 \\
\hline 12 & Real estate & 0,71 & 0,73 & 0,74 & 0,75 \\
\hline 13 & Jasa perusahaan & 0,36 & 0,37 & 0,38 & 0,41 \\
\hline 14 & Administrasi pemerintahan, pertahanan dan & 3,07 & 3,04 & 3,06 & 3,05 \\
& jaminan sosial wajib & & & & \\
\hline 15 & Jasa pendidikan & 5,97 & 6,31 & 6,28 & 6,43 \\
\hline 16 & Jasa kesehatan dan kegiatan sosial & 0,89 & 0,93 & 0,96 & 0,98 \\
\hline 17 & Jasa lainnya & $\mathbf{1 0 0 , 0 0}$ & $\mathbf{1 0 0 , 0 0}$ & $\mathbf{1 0 0 , 0 0}$ & $\mathbf{1 0 0 , 0 0}$ \\
\hline Produk Domestik Regional Bruto & & & & \\
\hline Sum & & & 1,77 & 1,73 & 1,76 \\
\hline
\end{tabular}

Sumber: Kabupaten Wonogiri Dalam Angka, 2017

Penyediaan saran dan prasaran seperti angkutan penumpang dapat memenuhi kebutuhan mobilitas masyarakat karena akan menghubungkan antar wilayah. Sarana Angkutan
Penumpang di Kabupaten Wonogiri ditunjukkan pada tabel 4. Sarana angkutan penumpang di Kabupaten Wonogiri tiap tahun mengalami penurunan dari tahun 2013 sebesar 
11.897 menjadi 6.475 tahun 2017. Hal ini menunjukkan berkurangnya sarana angkutan penumpang padahal sarana angkutan merupakan hal yang penting dalam memenuhi kebutuhan masyarakat di wilayah pelosok untuk menuju ke wilayah pusat pemerintahan maupun industri serta sarana angkutan penumpang sangat penting dalam mobilitas yang tinggi akan meningkatkan perekonomian di Kabupaten Wonogiri. Bagi masyarakat menengah kebawah yang tidak memiliki angkutan pribadi maka keberadaan angkutan umum sangat membantu baik sebagai angkutan penumpang ataupun angkutan barang

Tabel 4.

Sarana Angkutan Penumpang di Kabupaten Wonogiri Tahun 2013-2017

\begin{tabular}{|c|c|c|c|c|c|}
\hline Uraian & 2013 & 2014 & 2015 & 2016 & 2017 \\
\hline Bus AKAP & 563 & 520 & 539 & 525 & 525 \\
\hline Bus AKDP & 189 & 235 & 251 & 234 & 234 \\
\hline $\begin{array}{ll}\text { Minibus } & \text { Angkutan } \\
\text { Pedesaan } & \end{array}$ & 607 & 607 & 362 & 362 & 362 \\
\hline Angkuta & 85 & 85 & 85 & 85 & 85 \\
\hline Truk 2 As/Sumbu & 4.188 & 4.188 & 4.761 & 4.761 & 2.112 \\
\hline Truk 3 As/Sumbu & 125 & 125 & 131 & 131 & 42 \\
\hline Picup Box & 6.140 & 6.140 & 7.570 & 7.570 & 3.115 \\
\hline Jumlah & 11.897 & 11.900 & 13.699 & 13.668 & 6.475 \\
\hline
\end{tabular}

Sumber: Dinas Perhubungan Kabupaten Wonogiri tahun 2017

Tersedianya Infrastruktur air bersih yang digunakan masyarakat merupakan salah satu indikator atribut kuesioner yang digunakan dalam penilaian IDSD. Penyediaan air bersih pada masyarakat akan berpengaruh pada tingkat perekonomian di Kabupaten Wonogiri. Secara umum pemenuhan kebutuhan air bersih yang layak digunakan masyarakat yakni dengan sistem perpipaan dan non perpipaan. Persentase rasio jumlah pelanggan air bersih dibanding jumlah penduduk yang memanfaatkan jaringan air bersih berbasis PDAM dan Pamsimas (Perpipaan) ataupun dari sumur gali dan sumber air bersih lainnya (non perpipaan) di Kabupaten Wonogiri pada tahun 2016 yakni mencapai 80,31\%. Sedangkan $19,69 \%$ belum mendapatkan air bersih. Ada beberapa daerah yang belum terlayani air bersih seperti Kecamatan Paranggupito yang wilayahnya berupa pegunungan kars sehingga rawan kekeringan. Dari $80,31 \%$ yang telah terlayani, $54,31 \%$ dipenuhi melalui sambungan air bersih non perpipaan dan 25,99\% dari jaringan perpipaan (Bappeda dan Litbang Kab. Wonogiri, 2017). Beberapa indikasi yang menyebabkan belum tercapainya target untuk penyediaan sambungan air bersih disebabkan antara lain; (1) kondisi sarana air bersih yang belum layak, walaupun sarananya telah tersedia sehingga perlu untuk meningkatkan kualitasnya; dan (2) program penyediaan air bersih yang terkendala oleh kondisi fisik wilayah yang menyulitkan dalam implementasinya. Data pemenuhan sarana air bersih di Kabupaten Wonogiri tahun 2016 tersaji pada tabel 5 
Tabel 5.

Pemenuhan sarana air bersih di Kabupaten Wonogiri tahun 2016

\begin{tabular}{|l|r|r|r|}
\hline \multirow{2}{*}{ Sistem Jaringan } & \multicolumn{2}{|c|}{ Jumlah Terlayani } & \multicolumn{1}{l|}{ Prosentase } \\
\cline { 2 - 4 } & Sambungan rumah & \multicolumn{1}{|c|}{ Jiwa } \\
\hline Jaringan Perpipaan & 24.139 & 96.556 & 10,17 \\
\hline SAB Oleh pemerintah & 4062 & 16248 & 1,71 \\
\hline SAB Swadaya masyarakat & 33460 & 133840 & 14,1 \\
\hline PDAM & 246.644 & $\mathbf{2 5 , 9 8}$ \\
\hline Jml. Terlayani Perpipaan & \multicolumn{3}{|l}{} \\
\hline Jaringan Bukan Perpipaan & 105.502 & 422.008 & 44,46 \\
\hline Sumur gali & 1235 & 0,13 \\
\hline Sungai/Waduk & 80.871 & 8,52 \\
\hline mata air & 11.363 & 1,19 \\
\hline tadah hujan & 515.477 & $\mathbf{5 4 , 3 1}$ \\
\hline Jml. Terlayani Bukan Perpipaan & 762.121 & $\mathbf{8 0 , 3 1}$ \\
\hline Jumlah terlayani SAB air bersih & 186.898 & 19,69 \\
\hline Jumlah belum terlayani & 949.017 & 100 \\
\hline Jumlah penduduk & & & \\
\hline
\end{tabular}

Sumber: Bappeda dan Litbang Kab. Wonogiri, 2017

Listrik berperan penting dalam kehidupan, dimana listrik menjadi sumber energi utama baik untuk kebutuhan rumah tangga ataupun industri. Penyediaan listrik tersebut bertujuan untuk meningkatkan perekonomian masyarakat. Jumlah pengguna atau pelanggan listrik di Kabupaten Wonogiri dari rumah tangga sebesar 89,29\%. Jumlah tersebut tergolong rendah jika dibandingkan dengan pelanggan listrik di Kab/Kota di Jawa Tengah. Bahkan kabupaten Wonogiri menempati peringkat ke 31 berdasarkan data laporan realisasi elektrifikasi distribusi Jawa Tengah bulan Maret 2018 (tabel 6). Ada 9.119 rumah yang belum teraliri listrik yang tersebar di beberapa kecamatan di Kabupaten.
Ketidaktersediaan energi listrik merupakan salah satu indikator daerah tertinggal atau kemiskinan (Kristianto, 2015). Berdasarkan penelitian Anas dan Lee (1996), bahwa kekurangan kapasitas listrik menjadi hambatan besar pada perkembangan perusahaan di Nigeria. Infrastruktur listrik merupakan energi penting dalam pengembangan kehidupan manusia, listik digunakan untuk berbagai kegiatan baik di kota maupun di pedesaan. Kebutuhan listrik dari waktu ke waktu semakin meningkat seiring dengan pertumbuhan sosial masyarakat. Olehkarena itu ketersedianya jaringan listrik yang memadai bagi masyarakat dapat meningkatkan kesejahteraan masyarakat. 
Tabel 6.

Laporan Realisasi Rasio Elektrifikasi Distribusi Jawa Tengah Bulan Maret 2018

\begin{tabular}{|c|c|c|c|c|c|c|}
\hline $\mathrm{NO}$ & KABUPATEN & $\begin{array}{c}\text { JML. PLG } \\
\text { RMH } \\
\text { TANGGA }\end{array}$ & $\begin{array}{c}\text { JML. PLG } \\
\text { RMH } \\
\text { TANGGA } \\
\text { NON PLN }\end{array}$ & $\begin{array}{c}\text { JML. PLG } \\
\text { RMH } \\
\text { TANGGA } \\
\text { TOTAL } \\
\end{array}$ & $\begin{array}{l}\text { RE } \\
\text { PLN } \\
(\%)\end{array}$ & $\begin{array}{c}\text { RE } \\
\text { TOTAL } \\
(\%)\end{array}$ \\
\hline & $\begin{array}{c}\text { JAWA } \\
\text { TENGAH } \\
\end{array}$ & 8.988 .159 & 8.088 & 8.996.247 & 96,91 & 97 \\
\hline 1 & Cilacap & 478.715 & 320 & 477.035 & 99,71 & 99,37 \\
\hline 2 & Kebumen & 329.688 & 367 & 330.055 & 100,00 & 100,00 \\
\hline 3 & Klaten & 356.750 & 36 & 356.786 & 100,00 & 100,00 \\
\hline 4 & Boyolali & 257.057 & 141 & 257.198 & 91,72 & 91,77 \\
\hline 5 & Kudus & 236.374 & 0 & 236.374 & 100,00 & 100,00 \\
\hline 6 & Jepara & 264.075 & 2.351 & 266.426 & 83,53 & 84,27 \\
\hline 7 & Pati & 358.032 & 87 & 358.119 & 98,72 & 98,75 \\
\hline 8 & Rembang & 164.803 & 162 & 164.965 & 93,05 & 93,15 \\
\hline 9 & Blora & 226.728 & 141 & 226.869 & 89,36 & 89,42 \\
\hline 10 & magelang & 308.832 & 50 & 308.882 & 90,16 & 90,17 \\
\hline 11 & Kota Magelang & 32.076 & 0 & 32.078 & 94,96 & 94,96 \\
\hline 12 & Purworejo & 201.936 & 113 & 202.049 & 92,70 & 92,75 \\
\hline 13 & Temanggung & 191.996 & 80 & 192.076 & 95,12 & 95,16 \\
\hline 14 & $\begin{array}{l}\text { Kota } \\
\text { Pekalongan }\end{array}$ & 77.864 & 0 & 77.864 & 100,00 & 100,00 \\
\hline 15 & Pekalongan & 185.234 & 289 & 185.523 & 87,34 & 87,47 \\
\hline 16 & Batang & 186.256 & 295 & 186.551 & 97,45 & 97,60 \\
\hline 17 & Banyumas & 431.356 & 1.001 & 432.357 & 96,85 & 97,07 \\
\hline 18 & Purbalingga & 217.297 & 120 & 217.417 & 95,82 & 95,87 \\
\hline 19 & Banjarnegara & 241.995 & 611 & 242.606 & 99,98 & 100,00 \\
\hline 20 & Wonosobo & 211.814 & 300 & 212.114 & 98,05 & 98,19 \\
\hline 21 & Kota Salatiga & 50.235 & 0 & 50.235 & 100,00 & 100,00 \\
\hline 22 & Semarang & 273.414 & 0 & 273.414 & 100,00 & 100,00 \\
\hline 23 & Kota Semarang & 463.659 & 0 & 463.659 & 99,78 & 99,78 \\
\hline 24 & Demak & 292.244 & 0 & 292.244 & 97,18 & 97,18 \\
\hline 25 & Kendal & 270.877 & 7 & 270.884 & 100,00 & 100,00 \\
\hline 26 & Grobogan & 263.279 & 320 & 363.599 & 88,48 & 88,56 \\
\hline 27 & Surakarta & 136.866 & 0 & 136.866 & 89,49 & 89,49 \\
\hline 28 & Karanganyar & 240.200 & 20 & 240.220 & 100,00 & 100,00 \\
\hline 29 & Sukoharjo & 258.367 & 0 & 258.367 & 100,00 & 100,00 \\
\hline 30 & Sragen & 254.714 & 276 & 254.990 & 99,99 & 100,00 \\
\hline 31 & Wonogiri & 241.870 & 1.001 & 242.871 & $\mathbf{8 8 , 9 2}$ & 89,29 \\
\hline 32 & Tegal & 370.056 & 0 & 370.056 & 99,81 & 99,81 \\
\hline 33 & Kota Tegal & 67.377 & 0 & 67.377 & 98,78 & 98,74 \\
\hline 34 & Brebes & 426.829 & 0 & 426.829 & 90,53 & 90,53 \\
\hline 35 & Pemalang & 321.294 & 0 & 321.294 & 100,00 & 100,00 \\
\hline
\end{tabular}

Sumber: ESDM Prov Jateng, 2018 


\section{SIMPULAN}

Hasil penilaian menunjukkan bahwa nilai Indeks Daya Saing Daerah Kabupaten Wonogiri pada pilar infrastruktur dibawah nilai rata-rata nilai indeks daya saing Kab/kota di Jawa Tengah. Pilar infrastruktur terbentuk dari dimensi infrastruktur transportasi dan dimensi infrastruktur air bersih dan kelistrikan. Penyebab rendahnya nilai daya saing daerah pada pilar infrastruktur, adalah: Dari dimensi transportasi, yakni Infrastruktur jalan dengan kondisi kurang baik/rusak masih ditemukan di beberapa daerah/kecamatan di Kab. Wonogiri. Selain itu sarana transportasi umum jumlahnya semakin menurun. Dari dimensi infrastruktur air bersih pada tahun 2016, Persentase rasio jumlah pelanggan air bersih dibanding jumlah penduduk yang memanfaatkan jaringan air bersih berbasis PDAM dan Pamsimas (Perpipaan) ataupun dari sumur gali dan sumber air bersih lainnya (non perpipaan) di Kabupaten Wonogiri yakni pada tahun 2016 yakni mencapai $80,31 \%$. Sedangkan $19,69 \%$ masyarakat belum mendapatkan air bersih. Dari dimensi kelistrikan, persentase pelanggan listrik di Kabupaten Wonogiri tahun 2018 adalah $89,29 \%$, namun beberapa rumah yang tersebar di beberapa kecamatan masih belum tersambung dengan aliran listrik.

Peningkatan kualitas dan kuantitas infrastruktur harus menjadi prioritas dalam mendukung efisiensi dan efektivitas mobilitas ekonomi dan sosial di Kabupaten Wonogiri. Oleh karena itu perlu upaya dari pemerintah daerah untuk mendorong pembangunan/perbaikan sektor infrastruktur untuk mengurangi kesenjangan antar wilayah dan meningkatkan perekonomian masyarakat. Rencana aksi untuk mewujudkan kebijakan tersebut yakni dengan penambahan anggaran APBD guna mendorong pembangunan infrastruktur. Mendorong alokasi dana desa/kelurahan untuk pembangunan infrastruktur baik infrastruktur jalan, air bersih maupun sambungan listrik. Sehingga dari kolaborasi antara dana desa dan anggaran dari APBD tersebut harapannya dapat menjadi solusi untuk mengatasi permasalahan terkait infrastruktur di Kabupaten Wonogiri.

\section{DAFTAR PUSTAKA}

Anas, A., Lee K.S. Murray M. 1996. Infrastructure Bottleneck, private Provision, and Industrial Productivity : A Study of Indonesia and Thai Cities. The World Bank, Policy Reaserch Working Paper No. 1603.

Bappeda dan Litbang Kabupaten Wonogiri. 2017. Laporan akhir Studi Kebijakan Pembangunan Infrastruktur Kabupaten Wonogiri Tahun 2017. Bappeda dan Litbang Kabupaten Wonogiri

Bappeda Provinsi jawa Tengah. 2018. Pedoman Teknis Penilaian Indek Daya Saing Daerah Kabupaten/Kota Provinsi Jawa Tengah Tahun 2018. Bappeda Provinsi Jawa Tengah. 
Bappeda Banyuwangi. 2015. Peningkatan Daya Saing Daerah. Badan Perencanaan Pembangunan Daerah dan Penelitian dan Pengembangan Kabupaten Banyuwangi.

BPS. 2017. Kabupaten Wonogiri Dalam Angka 2017. Badan Pusat Statistik Kabupaten Wonogiri.

Dinas Perhubungan. 2017. Sarana Angkutan Penumpang di Kabupaten Wonogiri Tahun 2017. Dinas Perhubungan Kabupaten Wonogiri.

Kemenristekdikti. 2018. Pedoman Teknis Penilaian Anugrah Iptek Budhipraja Tahun 2018. Kementrian Riset Teknologi dan Pendidikan. https://anugerahiptek.ristekdikti.go.id. Diakses pada 2 Juli 2018.

Kristianto, S. I. 2015. Analisis Konsumsi Listrik Rumah Tangga di Kecamatan Tembalang. Skripsi Program Studi Ilmu Ekonomi dan Studi Pembangunan Fakultas Ekonomika dan Bisnis Universitas Diponegoro. Semarang

Undang-undang Nomor 23 Tahun 2014 tentang Pemerintah Daerah.

Wasilan, A.Noor. 2015. Peranan Infrastruktur Terhadap Pertumbuhan Ekonomi dan Implikasi Pada Kebijakan Pembangunan di Kota Samarinda. Jurnal Mimbar Volume 31 Nomor 2 Hal. 359-366. 